\title{
Study of Formulation, Sensory Evaluation and Microbiological Study of Camel and Buffalo Milk based Khoa Burfi Blended with Watermelon Seeds
}

\author{
Jorawar Singh ${ }^{1}$, Basant Bais ${ }^{1}$, Rakesh Ranjan $^{2}$, Rajani Joshi $^{3}$, \\ Diwakar $^{4}$, Parma Ram ${ }^{1}$ and Ajay Sharma ${ }^{1}$ \\ ${ }^{1}$ Department of Livestock Products Technology, CVAS, RAJUVAS, \\ Bikaner-334001, Raj., India \\ ${ }^{2}$ ICAR-NRC on Camel, Bikaner, Rajasthan, India \\ ${ }^{3}$ Department of Veterinary Public Health, College of Veterinary and Animal Science, \\ RAJUVAS, Bikaner, India \\ ${ }^{4}$ Department of Veterinary Microbiology and Biotechnology, RAJUVAS, Bikaner, India \\ *Corresponding author
}

\section{A B S T R A C T}

\section{Ke y w o r ds \\ Khoa, Burfi, Sensory Properties, Standard Plate Count, Yeast and Mould Count, Coliform Count \\ Article Info \\ Accepted: 10 April 2020 Available Online: 10 May 2020}

The present study was aimed to estimate the sensory properties and microbiological study of camel and buffalo milk based khoa burfi. Four treatment samples were developed by using different combination with watermelon seeds in selected camel and buffalo milk khoa viz. Control (without watermelon seeds incorporation) and treatments T1,T2 and T3 with $10 \%, 20 \%$ and $30 \%$ watermelon seeds incorporation respectively. On the basis of sensory scores, the khoa burfi prepared by incorporation of $10 \%$ watermelon seeds level scored maximum for all the sensory attributes such as appearance, color, flavor, taste, overall acceptability and was selected for pursuing the storage studies. The selected camel and buffalo milk khoa burfi were subjected to refrigerated $\left(4 \pm 1^{\circ} \mathrm{C}\right)$ storage temperature and quality characteristics were evaluated at every 3 days interval upto a period of 15 days. The microbial load of standard plate count, increased significantly high $(\mathrm{P}<0.01)$ in the control and all treatment khoa burfi whereas the initial yeast and mould count was nil up to $6^{\text {th }}$ day of storage than increased significantly $(\mathrm{P}<0.05)$. No coliform counts were observed.

\section{Introduction}

In the western world, camel milk is experiencing a novel awareness in these days and even the FAO has stepped in promoting camel milk (Ramet, 2001). Camel milk is considered to have anti-cancer (Magjeed, 2005), hypo-allergic (Shabo et al., 2005) and anti-diabetic properties (Agrawal et al., 2003). High content of unsaturated fatty acids 
contributes to its overall dietary quality (Karray et al., 2005; Konuspayeva et al., 2008). Camel milk is rich in chloride. Chlorides contents ranged between 0.20 and $0.28 \mathrm{~g}$ per $100 \mathrm{~g}$, respectively and the mean value (g per $100 \mathrm{~g}$ ) was $0.26 \pm 0.01$ for chlorides (Khaskheli et al., 2005).

Buffalo milk has a high fat content and can be preserved naturally for longer periods due to high peroxidase activity. Buffalo milk contains more calcium, better calcium: phosphorous ratio and less sodium and potassium compared to cow milk, making it a better nutritional supplement for infants. Buffalo milk is preferred for the preparation of western and traditional (indigenous) milk and dairy products and is superior in nutritional terms.

In India 46 per cent of total milk production consumed as liquid milk and 54 per cent is converted into milk products (www.nddb.org/statistics/milkproduction).

Amongst the traditional milk products, khoa is an important indigenous heat coagulated, partially dehydrated milk product, popular in large section of population throughout the country. The chemical composition of khoa include 20-25\% humidity, $25-37 \%$ fat, $17-$ $20 \%$ protein, $22-25 \%$ lactose, 3.6-3.8\% ash and 100-103 ppm iron depending on whether it is made from cow, buffalo or mixed milk (Moulick and Ghatak, 1997). It contains relatively large amounts of building proteins, bone forming minerals and energy giving fat and lactose. Most fat-soluble vitamins A, D, E and $\mathrm{K}$ are also expected to be retained. Above all, milk conversion to Khoa is the best milk preservation method for a relatively longer period of time without the use of any natural or chemical preservatives.

In India, burfi is most popular khoa based milk sweet, white to light cream in colour with firm body and smooth to granular texture. Burfi was prepared by many research workers using various fruits like ber (Kathalkar, 1995), papaya and sapota (Khedkar et al., 2007), mango (Kadam et al., 2009), orange (Thaware et al., 2009), fig (Matkar \& Deshmukh, 2007) etc. These fruits enhance the acceptability of burfi to the masses as well as choosy classes. Other ingredients are also incorporated in different proportions to meet the special needs of flavor, body and texture.

Watermelon (Citrullus lanatus) being a very famous fruit in Rajasthan, refreshing and diuretic properties of its red flesh present inside, together with its pleasant taste, make it a popular choice for producing juices and salads or for vegetable and raita making. The watermelon contains important carotenoids such as $\beta$-carotene, carotene and Lycopene which are important in neutralizing free radicals in the body (Oseni \& Okoye, 2013), high in proteins and fats and can find applications as a protein source in various food formulations and preparation (El-Adway $\&$ Taha, 2001). This fruit is a rich natural source of lycopene (Perkins-Veazie et al., 2001). Intake of lycopene containing-products has been associated with a reduced incidence of coronary heart disease and some types of cancer (Giovannucci, 2002). Watermelon seeds are a good source of low-molecularweight polypeptides i.e. globulin, glutenin and albumin. Seeds are also rich in aspartic acid, glutamic acid and serine (Tabiri et al., 2016).

Nowadays, incorporation of fruit seeds in Khoa Burfi is gaining popularity amongst consumers due to typical, highly liked flavour and nutritional value. A new range of product in dairy industry, value addition as a supplement of different nutrients and high impact of growth and immune protective on the health of consumer are the advantages of developing this type of product. 
Therefore, an attempt was made to manufacture Khoa Burfi from Camel and Buffalo milk. However, a very little work has been reported about use of Watermelon Seed in value addition of Khoa Burfi. Considering these above facts in view the present research work was planned with the specific objectives to value addition of Khoa Burfi using Watermelon Seeds as growth and immune protective additive.

\section{Materials and Methods}

\section{Material collection and sample preparation}

Fresh camel milk was collected from camel dairy maintained at ICAR-NRC on Camel, Bikaner and fresh buffalo milk was collected from buffaloes maintained under the 'Buffalo Unit' of Dept. of LPT, CVAS, RAJUVAS, Bikaner. All samples were collected manually in sterile bottles and were kept under chilled condition to perform the different experiments.

\section{Formation and accessibility of camel and buffalo milk based khoa burfi blended with or without watermelon seeds}

Formation of khoa was done by using different ratio of camel and buffalo milk. Best result was obtained on the basis of high yield, consistency of khoa and low cost of production by combination of $50 \%$ camel milk and $50 \%$ buffalo milk. On the basis of evaluation for quality parameters like yield, consistency of khoa, cost of production, sensory evaluation and physico-chemical characteristics, optimum ratio of admixture of camel and buffalo milk was determined.

Burfi was prepared as per the method described by Reddy (1985). Received milk was preheated at $35-40^{\circ} \mathrm{C}$ before filtration. Then milk was filtered in order to remove the visible dust and dirt particle. The process involved standardization of camel and buffalo mixed milk to 6 per cent fat and 9 per cent SNF, taken in an iron karahi and heated on gentle fire. At the time of boiling, milk was stirred with the help of a khunti in a circular manner. The stirring-cum-scrapping process was continued till a pasty consistency was reached. Then temperature was lowered upto $77-79^{\circ} \mathrm{C}$. At this stage, watermelon seeds as per treatment and sugar @ 30 per cent of khoa were added. Finally this mixture was heated on a low fire with stirring till the desired texture was obtained. It was then spread in a tray and allowed to cool. After setting, camel and buffalo milk khoa based watermelon seeds burfi was cut into rectangular blocks and stored at refrigeration $\left(4 \pm 1^{\circ} \mathrm{C}\right)$ followed by packaging.

\section{Product development}

Various levels of watermelon seeds powder incorporated camel and buffalo milk based khoa burfi by inclusion of $10 \%$ watermelon seeds powder, $20 \%$ watermelon seeds powder and $30 \%$ watermelon seeds powder were used for preparation of treatment burfi under investigation.

$\mathrm{T}_{0}-100$ parts of buffalo and camel milk khoa by weight +0 Parts of

Watermelon seeds powder, $\mathrm{T}_{1}-90$ parts of buffalo and camel milk khoa by weight +10 Parts of

Watermelon seeds powder, $\mathrm{T}_{2}-80$ parts of buffalo and camel milk khoa by weight +20 Parts of

Watermelon seeds powder, $\mathrm{T}_{3}-70$ parts of buffalo and camel milk khoa by weight +30 Parts of

Watermelon seeds powder.

\section{Sensory evaluation}

The samples of khoa burfi were subjected to sensory evaluation on 8 point hedonic scale 
by a panel of eight semi-trained members from academic staff and students of the department for various sensory attributes viz., appearance \& colour, flavour, body \& texture and overall acceptability using 8 point descriptive scale where ' 8 ' denotes 'Excellent' and ' 1 'denotes 'extremely poor'. Khoa burfi samples were presented in plastic plates. All samples were marked with digital code, and the order of presentation of samples was randomized for each panelist.

\section{Microbial tests}

All samples were assessed for microbial status, i.e. standard plate counts, coliform count and yeast and mould count as per standard procedures. The drawing of the representative sample of the khoa burfi and its preparation for the microbiological examination was carried out under the standard procedure.

\section{Standard plate count}

The standard plate counts of khoa burfi samples was evaluated by using method described in IS: 5402 (1969). The $11 \mathrm{~g}$ of khoa burfi sample aseptically weighed and transferred into a sterile $99 \mathrm{ml}$ dilution blank and mixed well. The samples were properly diluted by serial dilution by using $9 \mathrm{ml}$ phosphate buffer. Then from 2nd, 3rd and 4th dilution of khoa burfi samples were used for plating.

One ml diluent from each sample was taken in duplicate into the sterile petriplates with the help of sterile pipettes. Then the standard plate count agar media was added to these Petriplates and properly rotated so as to mix the content well. The plates were allowed to solidity. All the solidified plates were incubated at $37^{\circ} \mathrm{C}$ for $48 \mathrm{hrs}$ in an incubator in an inverted position and the number of colonies developed was recorded as $\mathrm{cfu} / \mathrm{g}$.

\section{Coliform counts}

The serial dilutions prepared for standard plate count were used for coliform count. The diluents from 1st and 2nd dilutions of khoa burfi samples were used for plating. The $1 \mathrm{ml}$ diluents from each was taken in duplicate in petriplates and then $10-15 \mathrm{ml}$ violet red bile agar media was added and mixed well. The plates were allowed to solidify. The plates were again overlaid with the same violet red bile agar media and allowed to solidify. Then the plates were incubated at $37^{\circ} \mathrm{C}$ for $24 \mathrm{hrs}$ in an incubator. The number of coliform colonies was recorded as cfu/g. The coliform colonies were with dark red centered and pinkish periphery.

\section{Yeast and mould count}

The yeast and mould count of khoa burfi samples were determined by using method described in IS: 5403 (1969). The serial dilutions prepared for standard plate count were used for enumeration of yeast and mould count. The diluents from $1^{\text {st }}$ and $2^{\text {nd }}$ dilutions of khoa burfi samples were used for plating. One $\mathrm{ml}$ each was taken in duplicate in petriplates and the Potato Dextrose Agar (PDA) was used by adjusting $\mathrm{pH} 3.5$ by using $10 \%$ sterilized tartaric acid solution. After solidification, the agar plates were incubated at $25^{\circ} \mathrm{C}$ for 5 days. At the end of incubation period count of the colonies of yeast and mould were recorded as $\mathrm{cfu} / \mathrm{g}$.

\section{Statistical analysis}

All the experiments of study were repeated three times and samples were drawn in duplicate. Data collected during the present investigation were subjected to statistical analysis by adopting appropriate methods of analysis of variance as described by Snedecor and Chochran (1994). 
Wherever, the variance ratio were found significant at 5 per cent and highly significant at 1 per cent levels of probability, the significance of mean differences were tested by Duncan's New Multiple Range Test (Duncan's Range Test) as modified by Kramer (1957).

\section{Results and Discussion}

\section{Sensory evaluation}

The result of sensory evaluation of camel and buffalo milk based khoa burfi blended with watermelon seeds have been presented in Table 1 and figure 2 . The result of sensory evaluation for different treatments in Table 1 indicate that the panelists, on average, prefer the treatment $\mathrm{T}_{1}(10 \%$ watermelon seed powder incorporated camel and buffalo milk khoa burfi) for appearance/colour, flavor, body/texture and overall acceptability.

A highly significant difference $(\mathrm{p}<0.01)$ was observed between samples for flavor and overall acceptability whereas a significant difference $(\mathrm{p}<0.05)$ was observed for appearance and colour except body and texture which was found to be non-significant as shown in Table 2. Thus it may be concluded that the different levels of watermelon seeds significantly affect the all sensory quality of camel and buffalo milk based khoa burfi except body and texture.

The results of sensory evaluation in present study are in accordance with the results reported for sweet orange burfi (Wadewale, 2010), date burfi (Pawar, 2011), ash gourd burfi (Nikam, 2012), pineapple burfi (Bankar et al., 2013), figure millet burfi (Kapare, 2017) and green peas burfi (Lahankar, 2017) in which $10 \%$ incorporation of respective ingredient was selected as best with respect to other treatments.

\section{Microbial analysis}

Most of the physico-chemical changes like acidity development, change in $\mathrm{pH}$ etc., are affected by the presence and growth of various microorganisms. Therefore the stored samples of khoa burfi were subjected to microbiological analysis for standard plate count (SPC), yeast and mould count (YMC) and coliform count. The changes observed in microbial quality of the khoa burfi, prepared with or without incorporation of watermelon seeds powder during assessment at a regular interval of 3 days under refrigerated temp ( $4 \pm$ 10C) during storage study have been presented for standard plate counts and yeast and mould counts under refrigerated storage condition for $0,3,6,9,12$ and 15 days. No coliform counts were observed during this storage duration.

\section{Standard plate count}

The major spoilage of khoa burfi is due to the growth of microbes. Hence, the SPC of khoa burfi samples were studied. The data related to standard plate count (SPC) of samples have been shown in Table 3 and depicted in figure 3.

During storage of khoa burfi at refrigerated temperature, a highly significant $(\mathrm{P} \leq 0.01)$ increase in SPC up to 15th day was observed and there after the product was found unacceptable due to visible mould growth.

The recorded results are in concord with the findings of Palit and Pal (2005) for burfi, Prabha (2006) for dietetic burfi and Londhe (2006) for peda. Increase in SPC of burfi samples during storage had been also reported by several other researchers viz. Sachdeva and Rajorhia (1982), Bhatele (1983), Reddy (1985), Mandokhot and Garg (1985), Mishra and Kuila (1988) in various other products as well. 
However, Kumar et al., (1997) did not observe any microbial growth in peda packaged under modified atmosphere packaging (MAP).

The data related analysis of variance for standard plate count of camel and buffalo milk khoa burfi revealed a highly significant difference $(\mathrm{P}<0.01)$ for between treatment and between period whereas non-significant difference for interaction between treatment and period was observed as shown table 4 .

\section{Yeast and mould count}

For most of the intermediate moisture Indian dairy foods such as Peda, Burfi, Kalakand, etc. mould growth tends to be a major problem and often most important single factor limiting their shelf life. Hence, yeast and mould counts were studied. The mean \pm SE values of yeast and mould counts of samples and storage periods has been presented in the table 5 and figure 4 whereas analysis of variance in table 6 .

The numbers of the fungal colonies obtained during present investigation are similar to various workers who had analyzed the milk products like Peda, Burfi and Kalakand (Biradar et al., 1985), Dwarkanath and
Srikanta (1977), Sachdeva and Rajorhia (1982) who reported increase in yeast and mould count during storage of burfi at $30 \pm$ $2^{\circ} \mathrm{C}$ and $7 \pm 2{ }^{\circ} \mathrm{C}$.

The data related to analysis of variance for yeast and mould count of camel and buffalo milk khoa burfi, presented in table 6 revealed a highly significant difference $(\mathrm{P}<0.01)$ that was observed between period and between treatment but the interaction between treatment and period was non-significant for yeast and mould count.

\section{Coliform count}

The growth of coliform count shows unhygienic production of the khoa burfi. Hence, the coliform counts of khoa burfi samples were studied. The product was found to be free from coliforms and during storage period $0^{\text {th }}, 3^{\text {rd }}, 6^{\text {th }}, 9^{\text {th }}, 12^{\text {th }}$ and $15^{\text {th }}$ day of refrigerated storage there was no coliform count observed. Similar studies were conducted to evaluate the coliform count and no coliform was reported by other workers (Gupta et al., (2010), Venkata et al., (2017) and Vasava et al., (2018)). The coliform count of burfi was $1.61 \times 10^{4} \mathrm{cfu} / \mathrm{gm}$ observed (Dwarakanath and Srikanta, 1977).

Table.1 Effect of various levels of watermelon seed on sensory quality of camel and buffalo milk burfi (mean $\pm \mathrm{SE})$

\begin{tabular}{|c|c|c|c|c|}
\hline Type of khoa & Flavour & $\begin{array}{c}\text { Body and } \\
\text { texture }\end{array}$ & $\begin{array}{c}\text { Appearance } \\
\text { and colour }\end{array}$ & $\begin{array}{c}\text { Overall } \\
\text { acceptability }\end{array}$ \\
\hline $\mathbf{T}_{\mathbf{0}}$ & $7.0^{\mathrm{b}} \pm 0.408$ & $6.5 \pm 0.289$ & $7.0^{\mathrm{ab}} \pm 0.408$ & $6.84^{\mathrm{bc}} \pm 0.207$ \\
\hline $\mathbf{T}_{\mathbf{1}}$ & $7.5^{\mathrm{b}} \pm 0.289$ & $7.0 \pm 0.408$ & $7.5^{\mathrm{b}} \pm 0.289$ & $7.34^{\mathrm{c}} \pm 0.188$ \\
\hline $\mathbf{T}_{\mathbf{2}}$ & $6.5^{\mathrm{b}} \pm 0.289$ & $6.0 \pm 0.408$ & $6.5^{\mathrm{ab}} \pm 0.289$ & $6.34^{\mathrm{b}} \pm 0.188$ \\
\hline $\mathbf{T}_{\mathbf{3}}$ & $5.5^{\mathrm{a}} \pm 0.289$ & $5.8 \pm 0.479$ & $6.0^{\mathrm{a}} \pm 0.408$ & $5.75^{\mathrm{a}} \pm 0.218$ \\
\hline
\end{tabular}

Note- Means bearing different superscript in a column (small letter) differ significantly. 
Table.2 Analysis of variance of sensory quality (between treatments) for camel and buffalo milk based khoa burfi blended with watermelon seeds

\begin{tabular}{|c|c|c|c|}
\hline Parameter & D.F. & Mean square & Level of sig. \\
\hline Flavour & 3 & 2.9166 & S** \\
\hline Body and texture & 3 & 1.2291 & NS \\
\hline Appearance and colour & 3 & 1.6666 & S* \\
\hline Overall acceptability & 3 & 5.520833 & S** \\
\hline
\end{tabular}

$* *=$ Highly Significant $(\mathrm{P}<0.01), *=$ Significant $(\mathrm{P}<0.05)$ and NS $=$ Non-significant

Table.3 Standard plate count $\log (\mathrm{cfu} / \mathrm{g})($ mean \pm SE) of camel and buffalo milk khoa burfi

\begin{tabular}{|c|c|c|c|c|c|}
\hline Day & $\mathbf{T}_{\mathbf{0}}$ & $\mathbf{T}_{\mathbf{1}}$ & $\mathbf{T}_{\mathbf{2}}$ & $\mathbf{T}_{\mathbf{3}}$ & Overall \\
\hline Day 0 & $3.72 \pm 0.041$ & $3.76 \pm 0.028$ & $3.82 \pm 0.101$ & $3.97 \pm 0.08$ & $\mathbf{3 . 8 1}^{\mathbf{a}} \pm \mathbf{0 . 0 4 2}$ \\
\hline Day 3 & $3.79 \pm 0.089$ & $3.86 \pm 0.025$ & $3.91 \pm 0.063$ & $4.06 \pm 0.117$ & $\mathbf{3 . 9 1}^{\mathbf{a b}} \pm \mathbf{0 . 0 4 6}$ \\
\hline Day 6 & $3.91 \pm 0.087$ & $3.95 \pm 0.013$ & $4.01 \pm 0.122$ & $4.14 \pm 0.083$ & $\mathbf{4 . 0 0}^{\mathbf{b c}} \pm \mathbf{0 . 0 4 7}$ \\
\hline Day 9 & $4.01 \pm 0.108$ & $4.06 \pm 0.068$ & $4.12 \pm 0.126$ & $4.22 \pm 0.122$ & $\mathbf{4 . 1 0}^{\mathbf{c d}} \pm \mathbf{0 . 0 5 4}$ \\
\hline Day 12 & $4.12 \pm 0.103$ & $4.15 \pm 0.062$ & $4.21 \pm 0.071$ & $4.30 \pm 0.109$ & $\mathbf{4 . 2 0}^{\mathbf{d e}} \pm \mathbf{0 . 0 4 6}$ \\
\hline Day 15 & $4.17 \pm 0.052$ & $4.22 \pm 0.109$ & $4.25 \pm 0.120$ & $4.34 \pm 0.084$ & $\mathbf{4 . 2 5}^{\mathbf{e}} \pm \mathbf{0 . 0 4 5}$ \\
\hline Overall & $\mathbf{3 . 9 5}^{\mathbf{A}} \pm \mathbf{0 . 0 5 2}$ & $\mathbf{4 . 0 0}^{\mathbf{A}} \pm \mathbf{0 . 0 4 4}$ & $\mathbf{4 . 0 5}^{\mathbf{B}} \pm \mathbf{0 . 0 5 2}$ & $\mathbf{4 . 1 7}^{\mathbf{C}} \pm \mathbf{0 . 0 4 7}$ & \\
\hline
\end{tabular}

Note:- A- Means bearing different superscript in a column (small letter) and in a row (capital letter) differ significantly. $\mathrm{T}_{0}-$ camel and buffalo milk khoa without any seed powder incorporation, $\mathrm{T}_{1}-$ camel and buffalo milk khoa with watermelon seed powder (10\%), $\mathrm{T}_{2}$ - camel and buffalo milk khoa with watermelon seed powder (20\%), $\mathrm{T}_{3}$ - camel and buffalo milk khoa with watermelon seed powder (30\%)

Table.4 Analysis of variance for SPC (Standard plate count)

\begin{tabular}{|l|c|c|c|}
\hline Source & D.F. & Mean square & Level of sig. \\
\hline Between period & 5 & 0.335313 & S** \\
\hline Between treatment & 3 & 0.172596 & S** \\
\hline Interaction between treatment and period & 15 & 0.000915 & NS \\
\hline Error & 48 & 0.025509 & \\
\hline
\end{tabular}

$* *=$ Highly Significant $(\mathrm{P}<0.01), *=$ Significant $(\mathrm{P}<0.05)$ and NS $=$ Non-significant

Table.5 Yeast and mould count $\log (\mathrm{cfu} / \mathrm{g})$ (mean \pm SE) of camel and buffalo milk based khoa burfi blended with watermelon seeds

\begin{tabular}{|c|c|c|c|c|c|}
\hline Day & $\mathbf{T}_{\mathbf{0}}$ & $\mathbf{T}_{\mathbf{1}}$ & $\mathbf{T}_{\mathbf{2}}$ & $\mathbf{T}_{\mathbf{3}}$ & Overall $^{\mathbf{2}}$ \\
\hline Day 0 to 6 & NIL & NIL & NIL & NIL & $\mathbf{0}^{\mathbf{a}}$ \\
\hline Day 9 & $0.73 \pm 0.039$ & $0.75 \pm 0.026$ & $0.82 \pm 0.057$ & $0.91 \pm 0.056$ & $\mathbf{0 . 8 0}^{\mathbf{b}} \pm \mathbf{0 . 0 2 9}$ \\
\hline Day 12 & $0.86 \pm 0.028$ & $0.88 \pm 0.042$ & $0.93 \pm 0.047$ & $0.99 \pm 0.054$ & $\mathbf{0 . 9 2}^{\mathbf{c}} \pm \mathbf{0 . 0 2 4}$ \\
\hline Day 15 & $0.92 \pm 0.017$ & $0.98 \pm 0.015$ & $1.03 \pm 0.026$ & $1.08 \pm 0.107$ & $\mathbf{1 . 0 0}^{\mathbf{d}} \pm \mathbf{0 . 0 3}$ \\
\hline Overall & $\mathbf{0 . 4 2}^{\mathbf{A}} \pm \mathbf{0 . 1 0 3}$ & $\mathbf{0 . 4 4}^{\mathbf{A B}} \pm \mathbf{0 . 1 0 7}$ & $\mathbf{0 . 4 6}^{\mathbf{B C}} \pm \mathbf{0 . 1 1 4}$ & $\mathbf{0 . 5 0}^{\mathbf{C}} \pm \mathbf{0 . 1 2 3}$ & \\
\hline
\end{tabular}

Note:- A- Means bearing different superscript in a column (small letter) and in a row (capital letter) differ significantly. 
Table.6 Analysis of variance for Yeast and mould

\begin{tabular}{|l|c|c|c|}
\hline \multicolumn{1}{|c|}{ Source } & D.F. & Mean square & Level of sig. \\
\hline Between period & 5 & 3.018224 & $\mathrm{~S}^{* *}$ \\
\hline Between treatment & 3 & 0.02156 & $\mathrm{~S}^{* *}$ \\
\hline Interaction between treatment and period & 15 & 0.00464 & $\mathrm{NS}$ \\
\hline Error & 48 & 0.003591 & \\
\hline
\end{tabular}

$* *=$ Highly Significant $(\mathrm{P}<0.01), *=$ Significant $(\mathrm{P}<0.05)$ and NS $=$ Non-significant

Receiving of Milk

(Camel milk 50\% and Buffalo milk 50\%)

$\downarrow$

Pre-heating $\underset{\downarrow}{\downarrow}\left(35-40{ }^{\circ} \mathrm{C}\right)$

Filtration

$\downarrow$

Standardization of milk

(6 per cent fat and 9 per cent SNF)

$\downarrow$

Boiling of milk with continuous stirring-cum-scrapping

$\downarrow$

Pasty consistency of khoa

$\downarrow$

Lowering of temperature upto $88-89^{\circ} \mathrm{C}$

$\downarrow$

Addition of sugar

(30 per cent by weight at khoa)

$\downarrow$

$\mathrm{T}_{0}-$ Control

(No watermelon seeds)
$\mathrm{T}_{1}$

(10\% watermelon seeds)
$\mathrm{T}_{2}$

(20\% watermelon seeds)
$\mathrm{T}_{3}$

(30\% watermelon seeds)<smiles>[AlH2]</smiles>

Continuous stirring with khunti on low flame up to solid mass stage

$\downarrow$

Spreading of product in tray and cooling

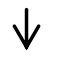

Setting of product

$\downarrow$

Cutting in to rectangular blocks

$\downarrow$

Packaging

$\downarrow$

Refrigerated storage $\left(4 \pm 1^{\circ} \mathrm{C}\right)$

Figure.1 Flow diagram for preparation of camel and buffalo milk based khoa burfi blended with or without watermelon seeds 


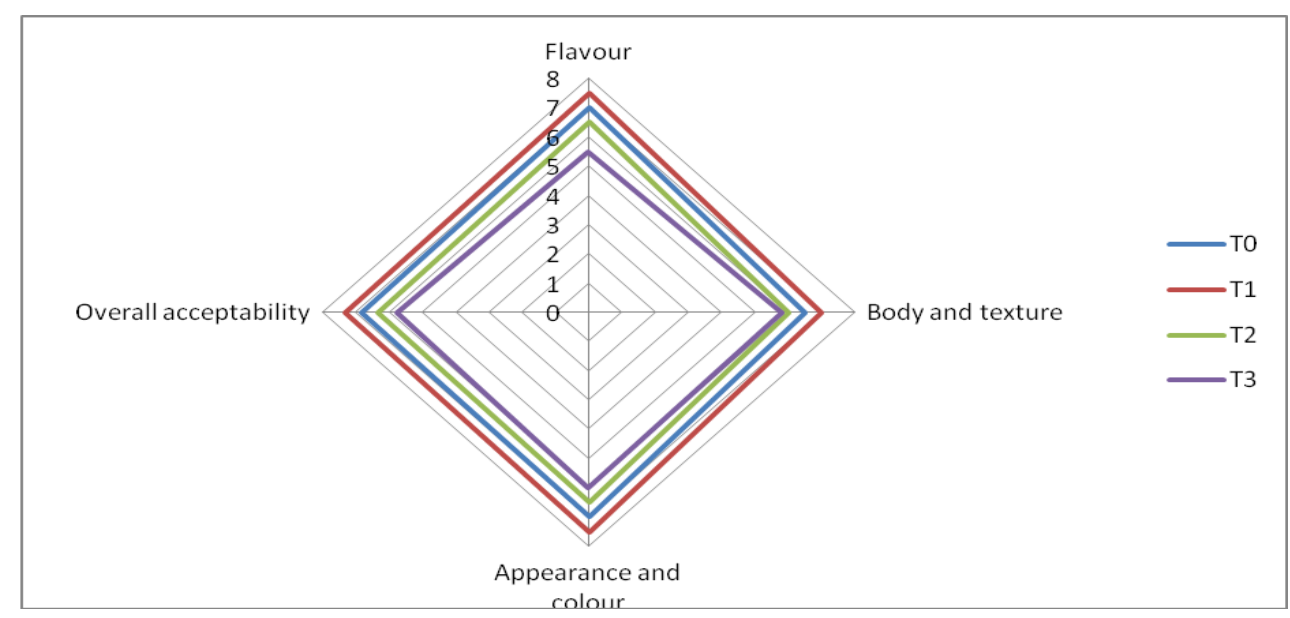

Figure.2 Effect of various levels of watermelon seed on sensory quality of camel and buffalo milk burfi

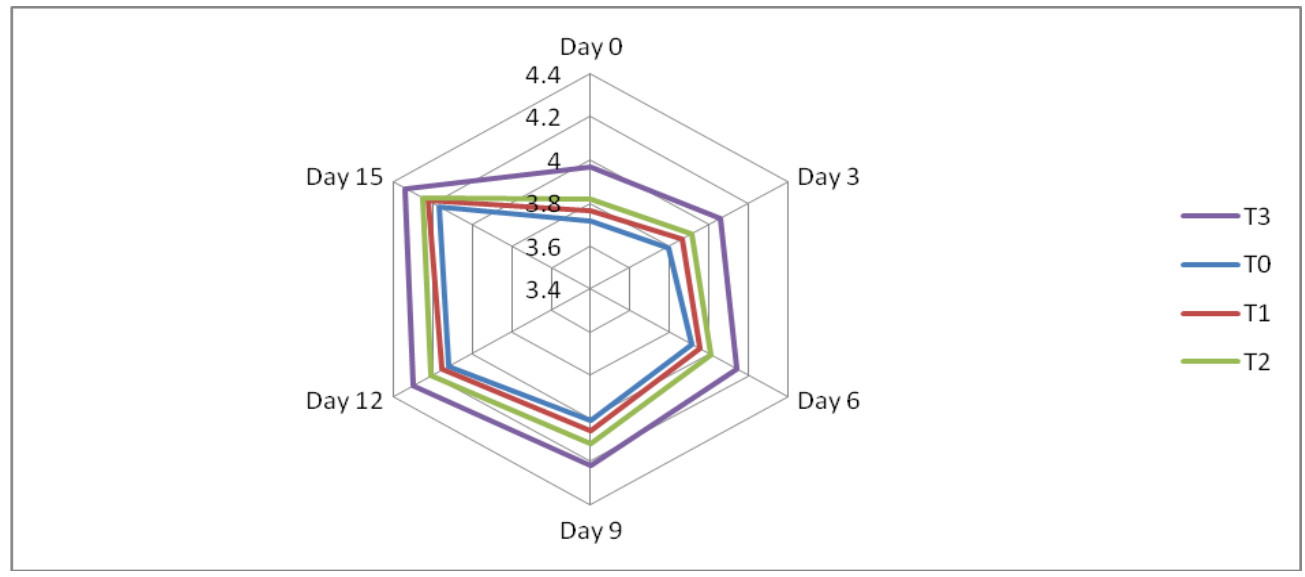

Figure.3 Standard plate count of camel and buffalo milk based khoa burfi blended with watermelon seeds
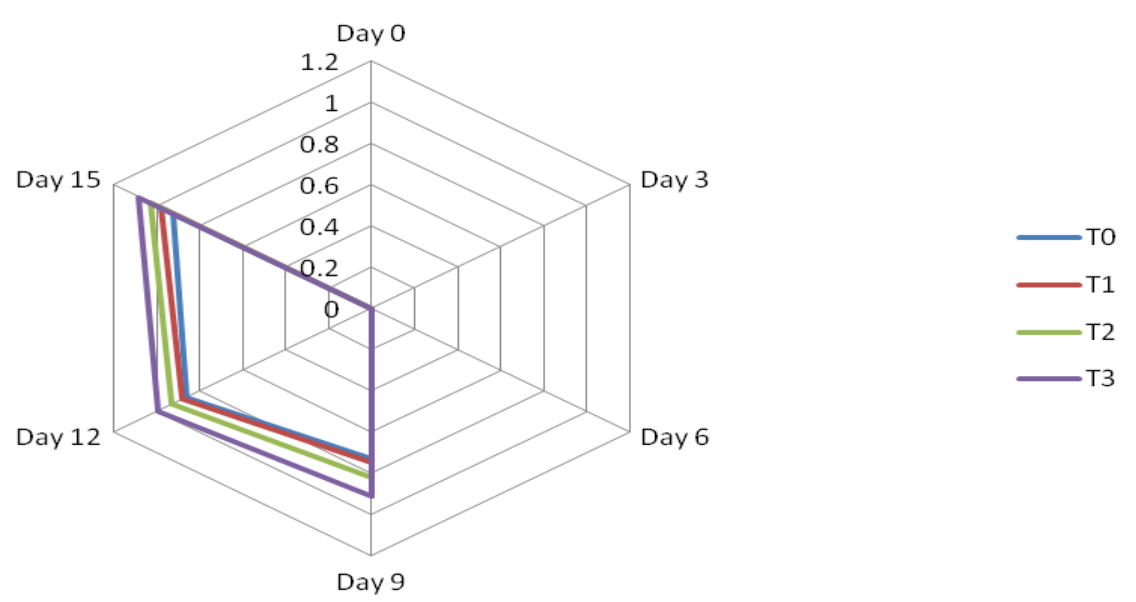

Figure.4 Yeast and mould count of camel and buffalo milk based khoa burfi blended with watermelon seeds 
Thus from the present study it may be concluded that the inclusion of watermelon seeds enhanced the sensory quality (flavour, color/appearance and overall acceptability) and overall acceptability of camel and buffalo milk khoa burfi.

It also concluded that watermelon seeds incorporated khoa burfi significant increase in nutritional properties and consumption of watermelon seeds as an adjunct in khoa based products will positively benefit the consumers.

\section{References}

Agrawal, R. P., Swami, S. C., Beniwal, R., Kochar, D. K., Sahani, M. S., Tuteja, F. C., et al., (2003). Effect of camel milk on glycemic control, lipid profile and diabetes quality of life in type-1 diabetes: a randomised prospective controlled cross over study. Indian Journal of Animal Science, 73, $1105 \mathrm{e} 1110$.

Bankar ,S.N., Barbind R.P., Korake R.L., Gaikwad S.V. and Bhutkar S.S., (2013). Studies on Preparation of Pineapple Burfi. Asian J. Dairy \& Food Res., 32 (1): $40-45$.

Bhatele, I.D. and Balachandran, R. (1983). XVIII Dairy Industry Conference, India (Madvas) Cited by C. R. Reddy and G. S. Rajorhia 1992. Indian J. Dairy Sci. 45 (5): 220-225.

Biradar US, Dev DK, Ingle UM (1985) Shelf life extension of pedha by packaging. $\mathrm{J}$ Food Sci 50:51-55

Dwarkanath, C.T. and S. Srikanta, (1977) Study on the microbiological quality of traditional Indian sweetmeat products. J. Food Sci. Technol., 14: 201-204.

El-Adawy, T.A. and Taha, K.M. (2001). Characteristics and composition of different seed oils and flours. Food
Chem., 74:47-54.

Giovannucci, E. (2002). A review of epidemiologic studies of tomatoes, lycopene, and prostate cancer. Experi. Bio. and Med. 227(10), 852-859.

Gupta, V., Vijayalakshmi, N.S., Ashwini, B., Anbarasu, K., Vijayalakshmi, G., Prakash, M., Indiramma, A.R., Rangarao, G.C.P. and Ramesh, B.S. (2010) Shelf life enhancement of coconut burfi-an Indian traditional sweet, Journal of Food Quality, 33, 329-349. DOI: $10.1111 / \mathrm{j} .1745-$ 4557.2010.00312. $\mathrm{x}$

IS : 5402, 1969. Estimation of total bacterial content using standard plate count methods. Indian Standards, Manak Bhavan, New Delhi.

IS : 5403, 1969. Method for yeast and mould count of foods stuffs. Indian Standard Institution, Manak Bhavan, New Delhi.

Kadam, R.M., Bhabure, C.V., Burte, R.G. and Joshi, S.V. (2009) Process standardization for manufacture of mango burfi. Souvenir of national seminar on novel dairy and food products of the future. September, 2009 SMC College of Dairy Sci., Anand pp 177-183

Kapare. P.B. (2017). Studies on preparation of finger millet burfi M.Sc. (Agri.) Thesis Submitted to Vasantrao Naik Marathwada Krishi Vidyapeeth, Parbhani.

Karray, N., C. Lopez, M. Ollivon and H. Attia. 2005. La matière grasse du lait de dromadaire: composition, microstructure et polymorphisme. Une revue Ol. Corps Gras Lipides 12:439446.

Kathalkar, V.B. (1995). Milk ber pulp burfi like product. M.Sc. (Agri.) thesis, Submitted to M.A.U., Parbhani (MS), India.

Khaskheli, M., M. A. Arain, S. Chaudhry, A. H. Soomro and T. A. Qureshi (2005). 
Physico chemical quality of camel milk. J. Agri. Soci. Sci. 2: 164-166.

Khedkar, J.N., Desale, R.J., Sakate, R.J. and Kotade, S.P. (2007). Use of fruit pulp in burfi. Souvenir. International conference traditional dairy foods. NDRI, Karnal. PP. 93.

Konuspayeva, G., E. Lemarie, B. Faye, G. Loiseau and D. Montet. 2008. Fatty acid and cholesterol composition of camel's (Camelus bactrianus, Camelus dromedarius and hybrids) milk in Kazakhstan. Dairy Sci. Technol. 88:327-340

Kramer, C. Y. (1957). Extension of multiple range tests to group of correlated adjusted means. Biometrics, 13, 13-18.

Kumar R., Bandyopadhyay P. and Punjarth J.S., (1997) "Shelf-life extension of peda using different packaging techniques", Indian J. Dairy Sci., 50(1), pp. 40-49.

Lahankar S.V. (2017). Studies on preparation of green pea burfi M.Sc. (Agri.) Thesis Submitted to Vasantrao Naik Marathwada Krishi Vidyapeeth, Parbhani.

Londhe G.K. (2006). Development of a process for manufacture and shelf life extension of brown peda. Ph.D Thesis, N.D.R.I., Karnal (Haryana), India.

Magjeed, N. A. (2005). Corrective effect of milk camel on some cancer biomarkers in blood of rats intoxicated with aflatoxin B1. Journal of the Saudi Chemical Society, 9, 253e263.

Mandokhot U.V. and Garg S.R. (1985). Market quality of khoa, burfi and pera: A critical review. J. Food Sci. Technol. 22: 299-304.

Matkar, S.P. and Deshmukh, B.R. (2007). Preparation of fig burfi. Souvenir. International conference on traditional dairy foods. NDRI, Karnal. PP. 79.

Mishra K. and Kuila R. K. (1988), "Microbiological quality of burfi and sandesh", Asian J. Dairy Res., 7(1), pp. 51-55.

Moulik, S. and Ghatak, P.K. (1997). Khoa- A review. J. Dairy Foods and Home Sci. 16(2): 73-86.

Nikam, M.S. (2012). Studies on preparation on ash gourd Burfi. M.Sc. (Agri) Thesis Submitted to Vasantrao Naik Marathwada Krishi Vidyapeeth, Parbhani.

Oseni, O. A and Okoye, V. I.: (2013) Studies of Phytochemical and Antioxidant properties of the Fruit of Watermelon (Citrullus lanatus). Journal of Pharmaceutical and Biomedical sciences; 27(27): 508-514. (Article no 14).

Palit C. and Pal D., (2005) "Studies on Mechanized production and shelf life extension of burfi", Indian J. Dairy Sci., 58(1), pp. 12-16, 2005.

Pawar, S.B. (2011). Studies on preparation of burfi blended with dried date. M.Sc. (Agri) Thesis Submitted to Vasantrao Naik Marathwada Krishi Vidyapeeth, Parbhani.

Perkins- Veazie, P., Collins, J. K., Pair, S. D., and Roberts, W. (2001). Lycopene content differs among red- fleshed watermelon cultivars. J. Sci. Food and Agri., 81(10), 983-987.

Prabha S. (2006). Development of technology for the manufacture of dietetic burfi", Ph.D Thesis, N.D.R.I., Karnal (Haryana), India.

Ramet, J. P. (2001). The technology of making cheese from camel milk (Camelus dromedarius). FAO Animal Production and Health Paper - 113, ISBN: 92-5-103154- 1

Reddy C.R. (1985). Process modification of production of khoa based sweets", Ph.D Thesis, Kurukshetra University, Kurukshetra (Haryana), India,

Reddy C.R. (1985). Process modification of production of khoa based sweets", Ph.D 
Thesis, Kurukshetra University, Vasava N.M. \& Paul, Preeti \& Pinto, Suneeta. Kurukshetra (Haryana), India,

Sachdeva, S. and Rajorhia, G. S. (1982). Technology and shelf life of burfi. Indian J. of Dairy Sci. 35 (4): 518-521.

Shabo, Y., Barzel, R., Margoulis, M., \& Yagil, R. (2005). Camel milk for food allergies in children. Immunology and Allergies, 7, 796e798.

Snedecor, G.W. and Cochran, W.G. (1994). Statistical methods, $8^{\text {th }}$ Edn.

Thaware, R. B., Ingale, Y.M., Zinjarde, R.M., Rokde, S.N. and Atkari, M.V. (2009). Preparation of burfi from goat milk blended with varying level of different fruit pulps. Indian J. of Dairy Sci, 62(2): 267-271 (2018). Effect of storage on PhysicoChemical, sensory and microbiological quality of gluten-free gulabjamun. The Pharma Innovation Journal; 7(6): 612619.

Venkata Satish Kuchi, J. Kabir, F.K. Bouri, Rajesh Gupta and Dhua, R.S. 2017. Influence of Packaging Materials on Quality of Banana Burfi during Storage. Int.J.Curr.Microbiol.App.Sci. 6(7): $118-127$

Wadewale, D.M. (2010). Studies on preparation of mandarin orange burfi. M.Sc. (Agri.) Thesis Submitted to Vasantrao Naik Marathwada Krishi Vidyapeeth, Parbhani

\section{How to cite this article:}

Jorawar Singh, Basant Bais, Rakesh Ranjan, Rajani Joshi, Diwakar, Parma Ram and Ajay Sharma. 2020. Study of Formulation, Sensory Evaluation and Microbiological Study of Camel and Buffalo Milk based Khoa Burfi Blended with Watermelon Seeds. Int.J.Curr.Microbiol.App.Sci. 9(05): 1231-1242. doi: https://doi.org/10.20546/ijcmas.2020.905.137 